\title{
Vultures in Cambodia: population, threats and conservation
}

\author{
TOM CLEMENTS, MARTIN GILBERT, HUGO J. RAINEY, \\ RICHARD CUTHBERT, JONATHAN C. EAMES, PECH BUNNAT, \\ SENG TEAK, SONG CHANSOCHEAT and TAN SETHA
}

\section{Summary}

Asian vultures have undergone dramatic declines of $90-99 \%$ in the Indian Subcontinent, as a consequence of poisoning by veterinary use of the drug diclofenac, and are at a high risk of extinction. Cambodia supports one of the only populations of three species (White-rumped Vulture Gyps bengalensis, Slender-billed Vulture G. tenuirostris and Red-headed Vulture Sarcogyps calvus) outside of South Asia where diclofenac use is not widespread. Conservation of the Cambodian sub-populations is therefore a global priority. This study analyses the results of a long-term research programme into Cambodian vultures that was initiated in 2004. Population sizes of each species are estimated at 50-200+ individuals, ranging across an area of approximately $300 \mathrm{~km}$ by $250 \mathrm{~km}$, including adjacent areas in Laos and Vietnam. The principal causes of vulture mortality were poisoning ( $73 \%)$, probably as an accidental consequence of local hunting and fishing practices, and hunting or capture for traditional medicine (15\%). This represents a significant loss from such a small population of long-lived, slow breeding, species such as vultures. Cambodian vultures are severely food limited and are primarily dependent on domestic ungulate carcasses, as wild ungulate populations have been severely depleted over the past 20 years. Local people across the vulture range still follow traditional animal husbandry practices, including releasing livestock into the open deciduous dipterocarp forest areas when they are not needed for work, providing the food source. Reducing threats through limiting the use of poisons (which are also harmful for human health) and supplementary food provisioning in the short to medium-term through 'vulture restaurants' is critical if Cambodian vultures are to be conserved.

\section{Introduction}

The South Asian vulture crisis has been well documented since the first dramatic declines were detected in India (Prakash 1999). Seven species of vultures are resident in South Asia, and three of these, White-rumped Vulture Gyps bengalensis (hereafter WRV) and Slender-billed Vulture Gyps tenuirostris (SBV) and Red-headed Vulture Sarcogyps calvus (RHV), are also resident in SouthEast Asia. These species were historically highly abundant in South Asia, as religious and cultural practices ensured a plentiful food supply of livestock carcasses (Houston 1985). Populations of resident vultures in South Asia declined rapidly during the 1990s and 2000s (Prakash 1999, Prakash et al. 2003, 2007, Gilbert et al. 2006, Pain et al. 2008, Das et al. 2011), as a consequence of veterinary use of diclofenac, a non-steroidal anti-inflammatory drug (Oaks et al. 2004). The drug is so toxic to vultures that the observed population declines could have been caused by the contamination of a very small proportion (between 1:130 and 1:760) of livestock carcasses (Green et al. 2004). By 2007, the population of WRV in India was reduced to one thousandth of 1992 levels, while SBV is thought to number only 1,000 individuals (Prakash et al. 2007), and RHV has been reduced to only $9 \%$ of the population that occurred in the early 1990s (Cuthbert et al. 2006). 
All of these species are now listed as "Critically Endangered" on the IUCN Red List (BirdLife International 2008) and at high risk of extinction. The Governments of India, Nepal and Pakistan have banned manufacturing and veterinary use of diclofenac. However, it is still currently used illegally for veterinary purposes and it is not known how long it will take for all use to cease. In the interim, conservation groups in South Asia have established captive breeding centres to ensure that some birds survive (Pain et al. 2008).

By contrast to South Asia, the vulture populations in South-East Asia declined much earlier. Three species, WRV, SBV and RHV, bred commonly in the first half of the $20^{\text {th }}$ century, ranging from Myanmar across Thailand and Indochina reaching Yunnan province in China and extending south to Peninsular Malaysia (Pain et al. 2003). By the 1980s, however, Thai populations of all three species had plummeted (Round and Chantrasmi 1985, Round 1988), and they had disappeared from Malaysia (Wells 1999) and Yunnan (Zheng Guangmei and Wang Qishan 1998). Widespread conflict meant that little was known from Indochina (Cambodia, Lao People's Democratic Republic (PDR) and Vietnam) until surveys in the late 1980s and 1990s. These surveys found that vultures were confined to areas bordering Cambodia in Lao PDR (Thewlis et al. 1998) and Vietnam (Le Xuan Canh et al. 1997, Brickle et al. 1998, Eames et al. 2004), and that all three species were widespread but nowhere abundant in the north and north-east in deciduous dipterocarp woodland of Cambodia (Barzen 1995, Desai and Lic Vuthy 1996, Timmins and Men 1998, Goes 1999, Long et al. 2000, Timmins and Ou 2001). Data are too sparse to determine the causes of this reduction in vulture range and abundance, but likely explanations include widespread collapses in populations of wild ungulates and changes in husbandry of domestic stock, as well as potentially direct persecution. By the 200os, therefore, South-East Asian populations of WRV, SBV and RHV were restricted to Myanmar (Hla et al. 2011) and Indochina, focused on an area of northern and eastern Cambodia measuring approximately 300 $\mathrm{km}$ east-west and $250 \mathrm{~km}$ north-south and including border areas in Lao PDR and Vietnam (Figure 1). These populations are not thought to have significant exposure to diclofenac and therefore represent the best long-term chance for in situ conservation.

This paper analyses the results of a long-term research programme on Cambodian vultures that was initiated by a consortium of Government agencies and non-governmental organisations (NGOs) in 2004 in response to the observed declines in South Asia (WCS et al. 2004). The principal research objectives were to analyse the threats to vulture species, understand ranging behaviour, monitor nesting sites, determine population sizes, and monitor trends at supplemental feeding sites to establish future management and conservation measures.

\section{Methods}

Research was undertaken at seven long-term research sites across the observed vulture range, chosen because vultures were known to be present or breeding (Figure 1): Preah Vihear Protected Forest (PVPF, since January 2003), Western Siempang (since December 2004), Phnom Prich Wildlife Sanctuary (PPWS, since July 2005), Lomphat Wildlife Sanctuary (LWS, since October 2005), Mondulkiri Protected Forest (MPF, since October 2005), Kulen Promtep Wildlife Sanctuary (KPWS, since April 2007) and the Seasan River (since June 2007). At each site a supplemental feeding station was established to monitor population trends and the surrounding area was surveyed for threats, nesting sites, and vultures every $1-2$ months by teams of local village rangers, for 10-20 days each month. Details of survey methodologies are given below. Research officers visited the sites for verification purposes and conducted additional surveys at other sites where vultures were recorded. Data are presented here until the end of June 2011.

\section{Threat assessments}

At each site, local village rangers recorded threats to vultures where they were encountered. All cases were investigated through interviews with local people to determine the details. In addition, 
(a) Red-headed Vulture

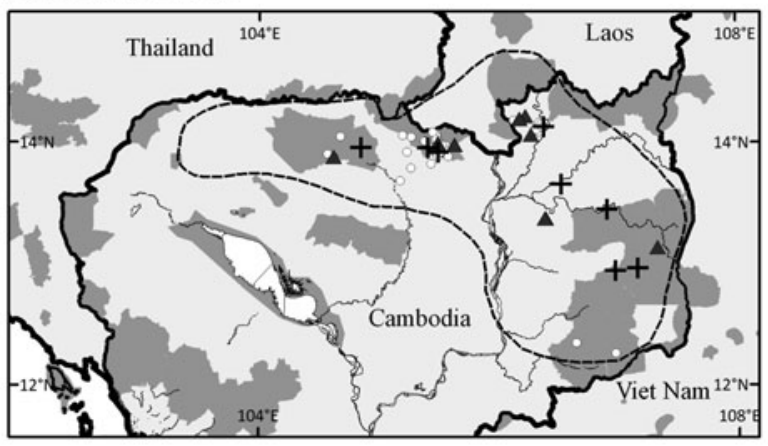

(b) Slender-billed Vulture (including satellite-tagged birds SBV3 and SBV4)

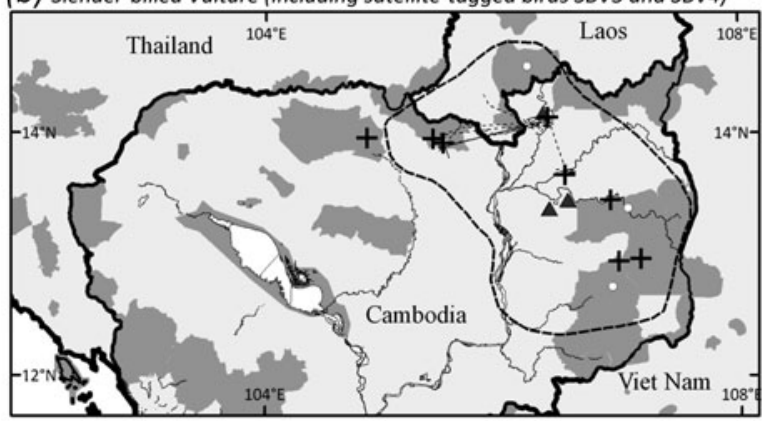

(c) White-rumped Vulture (including WRV6 and WRV8; WRV8 was subsequently found dead $270 \mathrm{~km}$ to the north of the capture point in Quang Nam province, Vietnam
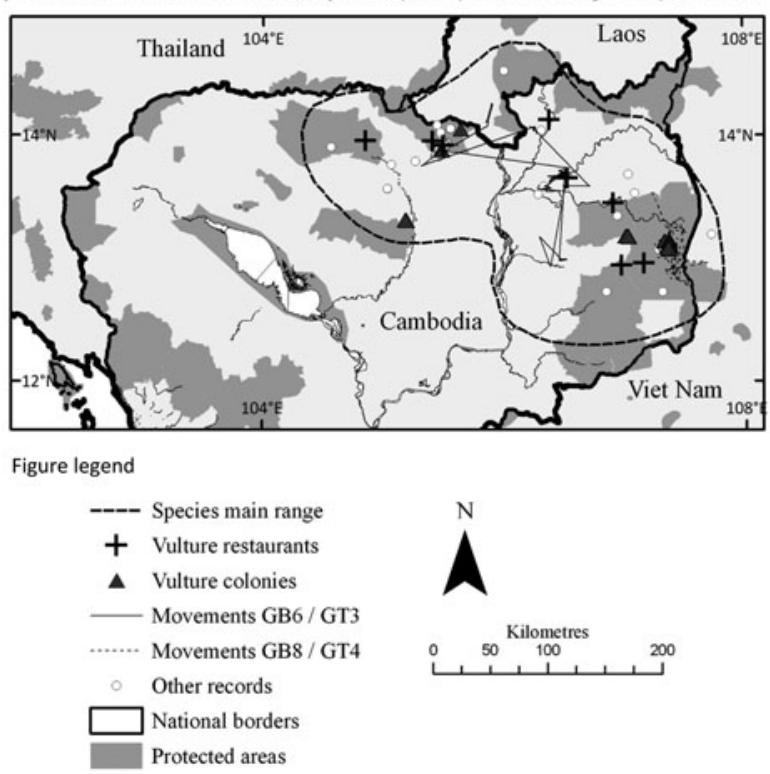

Figure 1. Distribution of Vultures in Indochina, showing long-term study sites, nesting colonies and data from satellite tagged birds. Data are based on the field surveys and records from the late 1990s onwards (see main text for references). 
research officers undertook comprehensive threat assessments through semi-structured interviews with key informants: local wildlife traders, hunters, government officials and veterinary establishments. Diclofenac availability was assessed through market surveys and interviews with pharmacies carried out by research officers, focusing on veterinary preparations and health products for livestock treatment. Data on human diclofenac preparations were also collected, since these can also be given to cattle. Diclofenac surveys were completed in all range provinces and in most district towns, and repeated at yearly intervals. The health status of vultures was assessed through examination of all birds that were trapped during the course of the project (see below) or were brought into care temporarily as a result of injury. Blood samples were taken for serology profiling, haemoparasitology, and phylogenetic studies.

Vulture food availability was assessed using two methods: field surveys for all types of carcass (wild and domestic animals) and household interviews regarding mortality of domestic livestock only. Field surveys for carcasses were undertaken at monthly intervals between 2005 and 2008 by local rangers at three sites (LWS, PVPF and Siempang). Suitable carcasses included domestic livestock (buffalo, cows, pigs and dogs) and wild ungulates such as gaur Bos gaurus, banteng B. javanicus, sambar Rusa unicolor, Eld's deer Rucervus eldii and wild pigs Sus scrofa. For each carcass found, the species, size, details of origin and the vultures present were recorded. Household interviews were conducted in 2004 by research officers in villages surrounding one site (PVPF), to determine the number of domestic livestock that were lost or died in the forest each year.

\section{Vulture ranging behaviour}

Satellite telemetry was used to determine vulture ranging behaviour. Vultures were caught at artificially baited feeding sites using a remotely operated Q-net (which uses high tension elastic to propel a $20 \times 16 \mathrm{ft}$ net), monofilament nooses and padded leg-hold traps. Capture rate was low as vultures were quickly sensitised to the techniques employed and became increasingly wary. Satellite transmitters (8o g Argos bird-borne transmitter, North Star Science and Technology LLC.) were fitted to two adult SBVs (SBV 3 and $\mathrm{SBV}_{4}$ ) and a WRV (WRV6) caught in May 2005 in PVPF, and an adult WRV (WRV8) captured in April 2006 in MPF. Home-range area was estimated using $100 \%$ minimum convex polygons generated using filtered fixes for each vulture using the software "Ranges7" (Kenward 2001; Kenward et al. 2003). Tracking resolution was set at $1,000 \mathrm{~m}$ to take account of the estimated accuracy of location classes.

\section{Monitoring nesting sites}

Vulture nesting sites were identified by local rangers, with specific targeted surveys during OctoberDecember (late wet season) when breeding commences. Nest surveys concentrated on known breeding locations, areas visited by satellite-tagged birds, and areas with emergent trees along watercourses and small hills, which are used by vultures in South Asia (Gilbert et al. 2006). Where nests were located, local people were employed as protectors, receiving a payment contingent on ensuring nests were not collected or disturbed by people. Data were recorded on vulture species, location and the characteristics of nesting sites and verified by research officers. Repeat visits by research officers were undertaken towards the end of the breeding season, in March and April (late dry season), in order to determine the number of chicks that successfully fledged.

\section{Monitoring vulture population size and trends}

Species populations were monitored at supplemental feeding stations ('vulture restaurants') established at each research site. Supplemental feeding was initiated because the threat assessments identified lack of food as one of the factors limiting vulture populations. Restaurants were conducted monthly by slaughtering one $150-250 \mathrm{~kg}$ cow or buffalo purchased from local villagers 
at each of the research sites, with the exception of MPF and PPWS where the restaurant was alternated on a bimonthly basis. Restaurant dates were staggered to maximise the food provisioning effect, allowing vultures to potentially move between restaurants across the range. Each restaurant was monitored until the carcass had been completely removed (usually 2-5 days). Data were collected on the vulture species present and age composition, with age classes recorded as adult, subadult (birds yet to attain adult plumage) and juvenile for WRV and SBV, and adult male, adult female and juvenile for RHV. Data were analysed using generalised linear models with quasiPoisson errors and a log-link function in R 2.12.2 (R Core Development Team 2011) to investigate differences between research sites and trends over time for each species. The selected models had the lowest quasi-AICc score and weights of at least 0.5 (Burnham et al. 2011).

The minimum number alive method (Krebs 1966) was used to estimate the minimum population of each species of vulture through an annual vulture census. The census was first conducted in July 2004, and repeated in May 2006 and annually thereafter. During the census, counts were undertaken simultaneously at multiple restaurants, both at research sites and other locations, throughout the vulture range. Since counts were simultaneous it was not possible for birds to travel between sites, preventing double counting. Two counts were conducted each year, separated by 10-14 days, during May-July, just after the breeding season. The maximum total number of each species recorded across all the census sites was used as the estimate of the minimum number alive.

\section{Results}

\section{Threat assessments}

Diclofenac availability: Veterinary use of diclofenac was not recorded from the range provinces, and formulations of the drug for veterinary use were only encountered once over the six years.

Poisoning and direct persecution: Poisoning was responsible for $60 \%$ of the 25 incidents of vulture deaths, leading to $74 \%$ of the 42 recorded mortalities (Table 1 ). Some poisoned birds were rescued and survived following veterinary care. Direct persecution (such as shooting of vultures with guns or slingshots) was the next most significant cause of vulture deaths, accounting for $10 \%$ of mortalities. One WRV from Phnom Tamao Wildlife Rescue Center and one RHV in Siem Reap province were killed for perceived value in Khmer medicine.

Food Limitation: Comprehensive field surveys at three sites over areas of approximately $500 \mathrm{~km}^{2}$ indicated that one carcass is available every 22-36 days (Table 2a). All carcasses encountered during surveys were domestic buffaloes, cows, or domestic dogs. A small number of wild ungulate and pig carcasses were recorded from research sites outside of the survey period. Household interviews in the villages using a $250 \mathrm{~km}^{2}$ area of PVPF, indicated that livestock densities are seven animals $\mathrm{km}^{-2}$. Every year around 18-32 animals died or were lost in the forest (Table 2b), an average of one domestic carcass every $11-21$ days. By contrast, densities of large wild ungulates in the study areas are approximately $1-3$ animals $\mathrm{km}^{-2}$ (Table $2 \mathrm{c}$ ). At least two birds, a RHV and a tagged WRV (WRV8) recovered in Quang Nam province in Vietnam, are thought to have died due to starvation. The poor body condition of both birds and location far outside the normal range is perhaps indicative of the difficulty vultures face in finding food.

Vulture health: Eleven of the 12 serum samples taken from captured vultures contained antibodies to avian encephalomyelitis virus, and one (RHV) had antibodies to avian paramyxovirus type I (Newcastle disease virus). However, only one mortality case from disease was recorded, a WRV at Phnom Tamao Wildlife Rescue Center that died during an outbreak of highly pathogenic avian influenza virus subtype $\mathrm{H}_{5} \mathrm{~N}_{1}$ (HPAI $\mathrm{H}_{5} \mathrm{~N}_{1}$ ) (Table 1 ).

\section{Ranging behaviour}

Minimum convex polygon (MCP) estimates of $2,315 \mathrm{~km}^{2}, 5,704 \mathrm{~km}^{2}$ and $12,155 \mathrm{~km}^{2}$ were obtained for three birds, WRV6, WRV8 and SBV 4 , which were tracked for 119,81 and 81 days 
Table 1 . Recorded incidences of vulture deaths or poisonings and the number of mortalities between November 2003 and the end of June 2011. Survey coverage was not equal in all years. RHV = Red-headed Vulture, SBV = Slender-billed Vulture and WRV $=$ White-rumped Vulture.

\begin{tabular}{|c|c|c|c|c|c|c|c|c|c|}
\hline \multirow[t]{2}{*}{ Cause of death } & \multicolumn{4}{|c|}{ Numbers of Incidences } & \multicolumn{4}{|c|}{ Number of Mortalities } & \multirow[t]{2}{*}{ Notes } \\
\hline & RHV & SBV & WRV & Total $(\%)$ & RHV & SBV & WRV & Total $(\%)$ & \\
\hline \multicolumn{10}{|l|}{ Human Origins } \\
\hline $\begin{array}{l}\text { - Use in human } \\
\text { medicine }\end{array}$ & 1 & & 1 & $2(8 \%)$ & 1 & & 1 & $2(5 \%)$ & $\begin{array}{l}\text { WRV was stolen } \\
\text { from a Zoo }\end{array}$ \\
\hline - Poisoned & 8 & 1 & 6 & $15(60 \%)$ & 7 & 1 & 23 & $31(74 \%)$ & $\begin{array}{l}\text { An additional } 6 \text { birds } \\
\text { survived }\end{array}$ \\
\hline - Killed & & 1 & 3 & $4(16 \%)$ & & 1 & 3 & $4(10 \%)$ & $\begin{array}{l}\text { Includes WRV6 } \\
\text { (shot in Laos) } \\
\text { and } \mathrm{SBV}_{4}\end{array}$ \\
\hline \multicolumn{10}{|l|}{ Disease } \\
\hline - Avian Influenza & & & 1 & I $(4 \%)$ & & & 1 & $I(2 \%)$ & WRV at the Zoo \\
\hline \multicolumn{10}{|l|}{ Other } \\
\hline $\begin{array}{l}\text { - Starving/Poor } \\
\text { condition }\end{array}$ & & & 2 & $2(8 \%)$ & & & 2 & $2(5 \%)$ & $\begin{array}{l}\text { Includes WRV8 } \\
\text { (found in Vietnam) }\end{array}$ \\
\hline - Unknown & & & 1 & $I(4 \%)$ & & & 2 & $2(5 \%)$ & \\
\hline Totals & 9 & 2 & 14 & 25 & 8 & 2 & 32 & 42 & \\
\hline
\end{tabular}

respectively. Due to the low number of independent points obtained for each bird, kernel contours could not be reliably calculated. Mortality of two vultures (WRV6 and SBV4) was confirmed 119 and 81 days after application of the transmitters while the units were still functional, and the death of WRV8 was confirmed 472 days after application, 13 months after the transmitter ceased functioning. Data are not given from one further bird, $\mathrm{SBV}_{3}$, whose satellite transmitter ceased functioning after only 12 days due to hardware failure.

\section{Nesting sites}

Nests of all three species were located, primarily at the LWS, PVPF, Seasan, Siempang, and MPF sites (Table 3). Causes of nesting failure included raiding by macaques Macaca fascicularis (10 WRV nests destroyed in the 2007-2008 season) or disturbances such as fire. SBV and WRV nested in separate colonies, WRV often beside rivers or on small hills, whereas RHV nested singly, although sometimes associated with colonies of both SBV and WRV. Nesting trees were large and tall, often of the Dipterocarpaceae family. In all cases only one chick per nest was observed.

\section{Vulture population size and trends}

Numbers of all three species of vulture have fluctuated significantly over time and between sites (Table 4). Greater numbers of RHV were also recorded in the wet season $(P<0.01$, Table 4$)$; the effect of season was not significant for the other species. There was a significantly positive relationship between the numbers of each species present. The total numbers of WRV and SBV at the restaurant sites increased strongly in the early years of the monitoring programme and have remained stable since 2008 (Figure 2), whereas numbers of RHV recorded are constant or declining slightly (Figure 2). Similar patterns are seen with the census data, with WRV increasing by $100 \%$ and SBV by $50 \%$ between 2004 and 2008 (Table 5). WRV numbers were greatest at the two northerly sites (PVPF and Siempang) that also recorded the largest increases, are stable at the two central sites (Seasan and LWS), and are declining at the two southerly and easterly sites 
Table 2. Availability of food for vultures from field surveys for wild and domestic animal carcasses and household interviews of mortalities of domestic livestock.

\begin{tabular}{|c|c|c|c|c|c|c|c|c|c|}
\hline \multirow[t]{2}{*}{ Site } & \multirow[t]{2}{*}{ Year } & \multirow{2}{*}{$\begin{array}{l}\text { Survey } \\
\text { Period }\end{array}$} & \multirow{2}{*}{$\begin{array}{l}\text { Wild Animal } \\
\text { Carcasses }\end{array}$} & \multicolumn{4}{|c|}{ Domestic Animal Carcasses } & \multirow{2}{*}{$\begin{array}{l}\text { Survey } \\
\text { Effort/Carcass }\end{array}$} & \multirow{2}{*}{$\begin{array}{l}\text { Carcass } \\
\text { density }\end{array}$} \\
\hline & & & & Buffalo & Cow & Dog & Total & & \\
\hline PVPF & $2005-6$ & 12 months & $\mathrm{o}$ & 3 & 6 & 1 & 10 & 36 days & $0.02 / \mathrm{km}^{2}$ \\
\hline Siempang & $2005-6$ & 12 months & o & 8 & 3 & 5 & 16 & 22 days & $0.03 / \mathrm{km}^{2}$ \\
\hline LWS & 2006-8 & 24 months & $\mathrm{O}$ & 5 & 19 & 2 & 26 & 28 days & $0.05 / \mathrm{km}^{2}$ \\
\hline
\end{tabular}

(b) Number of domestic livestock (cows and buffaloes) reported to have died or been lost in the forest in a $250 \mathrm{~km}^{2}$ area of PVPF, based on household interviews in 2002 and 2003. The projected total number lost or died in the forest is also given, based on applying the same mortality rates to all domestic livestock in the villages.

\begin{tabular}{llll}
\hline Site & Year & Number of domestic cows $/$ buffaloes & Domestic Livestock died or lost in forest \\
\hline PVPF & 2002 & $1752\left(\right.$ density $\left.=7 / \mathrm{km}^{2}\right)$ & 17 \\
& 2003 & & 32 \\
\hline
\end{tabular}

(c) Estimates of wild large ungulate populations and densities from field surveys

\begin{tabular}{llll}
\hline Site & Year & Density (animals $\left./ \mathrm{km}^{2}\right)$ & Reference \\
\hline PVPF & 2010 & WCS, unpublished data \\
PPWS & 2010 & Gray et al. 2011 & Gray et al. 2011 \\
MPF & 2010 & 3.8 & O'Kelly et al. 2011 \\
Seima & 2008 & 2.7 & \\
\hline
\end{tabular}


Table 3. Vulture nests recorded during 2004-2011 across all sites, and the number of birds known to have fledged.

\begin{tabular}{|c|c|c|c|c|c|c|}
\hline \multirow[t]{2}{*}{ Year } & \multicolumn{2}{|c|}{ Red-headed Vulture } & \multicolumn{2}{|c|}{ White-rumped Vulture } & \multicolumn{2}{|c|}{ Slender-billed Vulture } \\
\hline & Nests & Fledged & Nests & Fledged & Nests & Fledged \\
\hline $2004-5$ & 5 & no data & 32 & no data & & \\
\hline $2005-6$ & & & 28 & 5 & & \\
\hline $2006-7$ & 2 & 1 & 15 & 4 & 7 & 7 \\
\hline $2007-8$ & 2 & 1 & 19 & 5 & 6 & 4 \\
\hline $2008-9$ & 3 & 3 & 11 & 10 & 7 & 7 \\
\hline $2009-10$ & 3 & 3 & 25 & 25 & 8 & 8 \\
\hline $2010-11$ & 6 & 1 & 11 & 6 & 3 & 1 \\
\hline
\end{tabular}

(MPF and PPWS). Counts of SBV increased strongly at Siempang, which recorded the largest numbers, are relatively stable at PVPF, Seasan and LWS, and are also declining at MPF and PPWS. Vulture numbers were low in KPWS, to the far north-west of the other sites (data not shown). RHV numbers are low and stable at all sites, with the exception of MPF and PPWS where numbers are again declining. The percentage of juvenile and sub-adult birds was approximately $30 \%$ for each species (RHV 32\%, WRV 31\%, SBV 27\%) between January and March 2009, when reliable data are available. The minimum population size was $201 \mathrm{WRV}, 46 \mathrm{SBV}$ and 45 RHV in 2010; numbers counted were slightly lower in 2011 (Table 5).

Table 4. Generalised linear models for trends in the number of vultures recorded at the research sites, using quasi-poisson errors and a log link function. The selected models had the lowest quasi-AICc score and weights of at least 0.5 (Burnham et al. 2011). Significance values for the null hypothesis of zero effect: ns $=$ notsignificant, $\left.{ }^{*}=P<0.05,{ }^{* *}=P<0.01,{ }^{* * *}=P<0.001\right)$.

\begin{tabular}{|c|c|c|c|}
\hline Variable & $\begin{array}{l}\text { Degrees of } \\
\text { Freedom }\end{array}$ & $\begin{array}{l}\text { F-value } \\
\text { (significance) }\end{array}$ & $\begin{array}{l}\text { Coefficient } \\
\text { (significance) }\end{array}$ \\
\hline \multicolumn{4}{|l|}{ White-rumped Vulture } \\
\hline Date (polynomial function) & 2 & $8.80^{* * *}$ & \\
\hline Site & 5 & $120.31^{* * *}$ & \\
\hline Site ${ }^{*}$ Date (polynomial function) & 10 & $6.80^{* * *}$ & \\
\hline Number of Red-headed Vultures & 1 & $21.00^{* * *}$ & $0.013^{*}$ \\
\hline \multicolumn{3}{|c|}{ Residual deviance $=1850.6$ on 406 degrees of freedom } & $0.037^{* * *}$ \\
\hline \multicolumn{4}{|l|}{ Slender-billed Vulture } \\
\hline Date (polynomial function) & 2 & $3.87^{*}$ & \\
\hline Site & 5 & $133.57^{* * *}$ & \\
\hline Site ${ }^{*}$ Date (polynomial function) & 10 & $3.14^{* * *}$ & \\
\hline Season & 1 & 2.41 n.s. & $-0.160^{* *}$ \\
\hline Number of Red-headed Vulture & 1 & $34.25^{* * *}$ & $0.041^{* * *}$ \\
\hline Number of White-rumped Vulture & 1 & $118.58^{* * *}$ & $0.023^{* * *}$ \\
\hline \multicolumn{4}{|c|}{ Residual deviance $=859.6$ on 405 degrees of freedom } \\
\hline \multicolumn{4}{|l|}{ Red-headed Vulture } \\
\hline Date (polynomial function) & 2 & $12.97^{* * *}$ & \\
\hline Site & 5 & $43.87^{* * *}$ & \\
\hline Site ${ }^{*}$ Date (polynomial function) & 10 & $7.89^{* * *}$ & \\
\hline Season & 1 & $8.74^{* *}$ & $0.166^{* * *}$ \\
\hline Number of Slender-billed Vultures & 1 & $20.61^{* * *}$ & $0.024^{* * *}$ \\
\hline Residual deviance $=687.9$ on $406 \mathrm{~d}$ & freedom & & \\
\hline
\end{tabular}




\section{Discussion}

\section{Threats to Cambodian vultures}

Carnivorous and scavenging species are strongly limited by food availability (Krebs 2009). The three vulture species are obligate carrion feeders, feeding on carcasses of a range of species, including ungulates. Pain et al. (2003) suggest that food shortage in the latter part of the 2oth century may have played a major part in vulture declines in South-East Asia. Wild ungulate populations crashed in the region from uncontrolled hunting (Srikosamatara and Suteethorn 1995, Duckworth and Hedges 1998, Duckworth et al. 1999, Baillie et al. 2004), particularly in the open habitats where hunting is easier. Population estimates of large wild ungulates (gaur, banteng, Eld's deer, sambar and wild pigs) at the study sites and surrounding areas are less than four animals $\mathrm{km}^{-2}$ (Gray et al. 2011, O'Kelly et al. 2011, WCS unpubl. data). By contrast, densities of gaur and sambar alone at some national parks in India are approximately 16 animals $\mathrm{km}^{-2}$ (Jathanna et al. 2003), indicating that Cambodian densities are extremely low. Vultures are therefore likely to be highly dependent on domestic ungulates, which commonly exist at higher densities than wild ungulates (seven animals or more $\mathrm{km}^{-2}$ ). It should be noted that in parts of India, Pakistan and Nepal where WRV still occur, or occurred until recently, densities of domesticated bovines are typically 20-80 animals km${ }^{-2}$ (NDDB 2006, Wint and Robinson 2006). In Cambodia, traditional livestock husbandry practices allow animals to range freely across the deciduous forest for much of the year (particularly in the dry season), often unattended, where they may die or become lost, sometimes not returning for several years. Carcasses of animals that die in the forest may provide a significant supply of carrion for vultures if mortalities go undetected (otherwise meat is taken by local people). Insecurity and intensification of agriculture have led to a reduction in this practice in many Cambodian provinces (for example around Tonle Sap and the Mekong floodplain). The remaining vulture range corresponds exactly to those Cambodian provinces where livestock are still allowed to range freely.

Calculations based on the energetic requirements of vultures suggest that carcasses of domestic ungulates in Cambodia should be more than capable of supporting the population. Assuming a daily feeding requirement for a vulture is $0.341 \mathrm{~kg} /$ ungulate tissue per day (Swan et al. 2006 Protocol SI), a population of 300 birds requires an annual food availability of around $39,540 \mathrm{~kg}$ per year. This could be provided by around 1oo bovine carcasses per year, assuming an average carcass mass of $503 \mathrm{~kg}$ (for Bos taurus, B. indicus and Bubalus bubalis in South Asia; R. J. Cuthbert unpublished data) and that edible tissues comprise around $77 \%$ of a bovine live carcass weight (Green et al. 2006). Available data on the densities of domestic ungulate carcasses (Table 2), suggest that these food requirements could be met by livestock mortalities. However, what these calculations fail to estimate is the proportion of carcasses found by vultures and the proportion consumed by other scavengers, which is likely to be significant given the dense forests found across much of the vulture range in Cambodia. Moreover, the timing of carcass availability may be significant given that livestock generally return to villages during the wet season, when vultures may have to rely more on much scarcer wild ungulate carcasses. These calculations also suggest that the relatively modest feeding requirements of Cambodia's vultures (around 100 bovine carcasses per year) are increasingly well supplemented by restaurant sites, which supply around 70 carcasses per year. These calculations suggest that such modest supplementary feeding could be an effective conservation measure to overcome the issue of food limitation within Cambodia and this may help explain the increasing numbers of vultures recorded in Cambodia during the course of this study.

The major recorded source of mortality for Cambodian vultures is secondary poisoning, usually relating to the misuse of poisons (possibly organophospates normally used in agriculture) for hunting or fishing. Poisons are either emptied into waterholes (trapeangs), or delivered in bait such as rice, fish or fruit to catch scavenging species (such as storks) and frugivores. Vultures are not the intended targets of these activities, but die from consuming other animals that were killed 


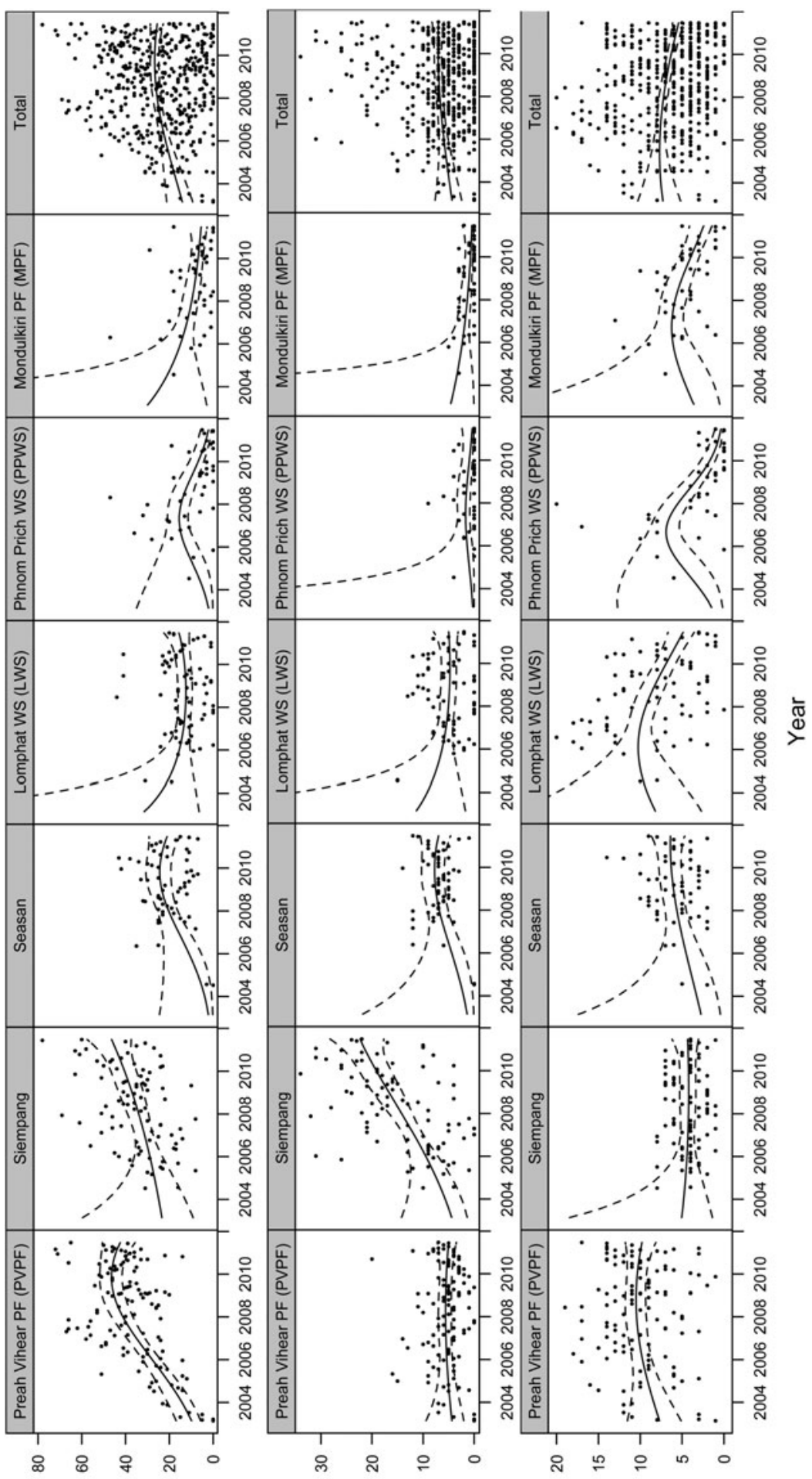

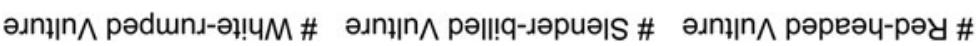


Table 5. Minimum vulture population size for Red-headed, White-rumped and Slender-billed vultures between 2004 and 2011 recorded during the vulture census.

\begin{tabular}{lllll}
\hline Date & \multicolumn{2}{l}{ Minimum Population Size } & & Total \\
\cline { 2 - 5 } & Red-headed Vulture & White-rumped Vulture & Slender-billed Vulture & 166 \\
\hline July 2004 & 42 & 90 & 34 & 238 \\
May 2006 & 58 & 149 & 31 & 226 \\
June 2007 & 40 & 160 & 26 & 290 \\
June 2008 & 48 & 191 & 51 & 266 \\
June 2009 & 43 & 182 & 41 & 292 \\
June 2010 & 45 & 201 & 46 & 267 \\
June 2011 & 39 & 183 & 45 & \\
\hline
\end{tabular}

from ingesting poisoned bait. Poisons such as strychnine or organophosphates, used for control of carnivores or other scavengers such as feral dogs (Cheke 1972), have also killed vultures in Cambodia. The social feeding behaviour of vultures combined with the scarcity of food in Cambodia increases the potential that groups of feeding birds may be affected by a single poisoning event. Poisoning is known to be a significant cause of vulture deaths in other regions (e.g. Hernández and Margalida 2008, 2009), and even low incidences of poisoning can cause dramatic declines in long-lived birds such as vultures if poisoning results in high mortality rates and breeding failure (Green et al. 2004; Oro et al. 2008).

A limited number of mortalities due to direct persecution, by firearms or home-made weapons or use in traditional medicine, were also observed. During the 1970s-1990s, firearms were highly abundant in Cambodia (Wille 2006), which may have led to widespread hunting and persecution of birds. However, the majority of these weapons have been brought under Government control or destroyed (EU ASAC 2009), which may have contributed to a significant reduction in hunting pressure from the late 1990s onwards. Vulture parts are not used in traditional Chinese medicine, but they may have some perceived value in Khmer medicine. At least two birds were taken for their parts and interview reports suggest that traders have visited villages within the remaining vulture range in Siempang and PVPF requesting capture of birds possibly for sale to Thailand or Lao PDR (Timmins et al. 2003).

There is limited evidence that diseases affect vultures in Cambodia, as the only known mortality due to disease was a captive bird during an outbreak of HPAI $\mathrm{H}_{5} \mathrm{~N}_{1}$ Almost all the vultures sampled carried antibodies to avian encephalomyelitis virus, indicating high rates of exposure, but the epidemiological significance of this is not clear. Avian encephalomyelitis is a picornavirus that causes neural deficits in young poultry, and has only rarely been reported in wild birds (galliforms and ducks; Gerlach, 1994).

Nesting birds in Cambodia are particularly vulnerable to collection and disturbance (Clements et al. 2010). Nest protection schemes, where local people are employed to guard vulture colonies and receive a bonus if the nest fledges, have proved effective at ensuring breeding is successful and locating new breeding sites. This is part of a wider programme in Cambodia that protects breeding sites for globally threatened species (Clements et al. 2010).

Cambodia remains the only country in the range of these vulture species where veterinary preparations of diclofenac are not widely available (based on extensive surveys), giving vultures an

Figure 2. Number of (a) White-rumped, (b) Slender-billed and (c) Red-headed vultures recorded at the six main vulture feeding stations and the total numbers for each species during January 2003June 2011. The predicted values and 95\% confidence intervals for the best fitting generalised linear model of vulture numbers are also shown. Sites are arranged in order from north-west to southeast. Data from KPWS are not shown as counts were low with $1-8$ RHV normally recorded. 
excellent chance of long-term survival. In early 2009, the National Institute of Animal Health in Cambodia ordered national veterinary staff to avoid use of diclofenac in veterinary treatments. Although this does not constitute a legal ban on the drug (as no list of legally approved veterinary medicines exists as yet), it is an important step in preventing this drug entering the vulture food chain in Cambodia.

\section{Population size and trends of vultures in Cambodia}

A successful monitoring programme must collect accurate data at a sufficient level of precision in order to detect population changes of a desired magnitude. It must also be within the capacity technical, financial and logistical - of management staff (Danielsen et al. 2008). In practice, achieving both of these is challenging. In India, monitoring was conducted using road surveys (Prakash et al. 2007), however trials in Cambodia concluded that vulture densities were too low for this technique to be effective and there are relatively few suitable roads bisecting the vulture range. Capture-mark resighting methods were evaluated and found to be unsuitable due to the low capture probabilities. Surveys of breeding sites yielded some population data, but detectability of nest sites is not known. The census was designed as a low-cost monitoring method that collected data on the minimum number of birds alive at one time (Krebs 1966). It is not possible to estimate the total number of vultures in the area, however, because the number of vultures that choose not to visit the restaurant sites is unknown. Results indicate a minimum of $201 \mathrm{WRV}, 48 \mathrm{SBV}$ and $47 \mathrm{RHV}$ in 2010. The numbers recorded are significant in comparison with the only other South-East Asian population in Myanmar, which was estimated at I4I WRV, 49 SBV and 3 RHV in 2006-2007 (Hla et al. 2011). However these counts were not undertaken simultaneously, so birds could have moved between sites, inflating the numbers recorded. The Myanmar results may therefore be overestimates and are not directly comparable to those from Cambodia.

Between 2004 and 2008 the number of WRV recorded in the census has doubled and SBV has increased by $50 \%$; numbers have been relatively unchanged since 2008 . The relationship between the census counts and actual population trends is, however, unclear. An increase in vulture numbers recorded by the census might be indicative of an increasing population, a decrease in food availability elsewhere in Cambodia (so more birds visit the census sites), or increased habituation of vultures to the regular feeding sites. At a minimum, the results indicate that the vulture population is unlikely to have declined since the conservation programme was initiated and perhaps is more likely to be increasing. Increases were strongest for WRV in the northern sites (PVPF and Siempang) and for SBV at Siempang, whilst strong decreases were seen for all species at the two southerly sites (PPWS and MPF). Given that it is unknown what proportion of birds are present but chose not to visit the restaurant sites, these results could either be due to changing numbers of vultures at those sites, or due to changes in the proportion of birds in the area visiting the restaurant. Vultures may become habituated to supplemental feeding sites (Piper 2006), which would cause an increase in the number observed even if there was no overall change in the population. Habituation is more likely for the northerly sites because the frequency of feeding events was much greater ( $1-3$ times per month, in comparison with once every $2-3$ months at the southerly sites), and because the density of wild ungulates (and hence other food sources) was lower.

Unlike WRV and SBV, RHV has a more cosmopolitan diet and can also feed on reptiles and other prey (Naoroji 2007); they are therefore less likely to be dependent on feeding from carcasses. RHV also may show a level of territorial behaviour, unlike the Gyps vultures, and have probably always existed at lower densities even in South Asia (del Hoyo et al. 1994). The lower numbers of RHV recorded at the restaurant sites are consistent with these behaviours. However, RHV are distributed more widely across Cambodia (Figure 1), possibly due to their more cosmopolitan diet, and hence the true population size of RHV may be significantly greater than the counts obtained.

Vultures range widely across northern and eastern Cambodia, with birds also recorded in southern Laos and border regions of Vietnam (Figure 1). Although a small number of vultures 
were tagged in this study for a relatively limited period, some comparisons can be made with a satellite telemetry study of five adult WRVs marked in Pakistan (Gilbert et al. 2007). These birds were tracked for 216 days and had home ranges of $68,930 \mathrm{~km}^{2}, 40,324 \mathrm{~km}^{2}, 4,625 \mathrm{~km}^{2}, 1,824 \mathrm{~km}^{2}$ and $5,069 \mathrm{~km}^{2}$ respectively. While there is clearly considerable variation in the home range of individual vultures, the fact that the home range of WRV6 and $\mathrm{SBV}_{4}$ exceeded that of three of the birds in Pakistan in a much shorter period of time suggests that birds may be ranging more widely in Cambodia. This observation would be consistent with variable foraging effort in environments where food is plentiful (Pakistan) and scarce (Cambodia).

\section{Conservation management}

Food provisioning for vultures, otherwise known as 'vulture restaurants', is widely used in the conservation and reintroduction of vulture populations in Africa (Mundy et al. 1992, Piper et al. 1999), Israel (Meretsky and Mannan 1999), Europe (Sarrazin et al. 1994, Carrete et al. 2006) and condors in North America (Wilbur et al. 1974). Restaurants are thought to have both positive and negative impacts on vultures (Piper 2006). Positive impacts could include increased nesting success as has been documented on other threatened raptors (González et al. 2006, but see Margalida 2010), improved survival rates (Oro et al. 2008), and provision of a safe food source free from potential poisons (Gilbert et al. 2007, Oro et al. 2008). However, supplemental feeding also changes the temporal and spatial distribution of food resources so that they become more predictable (Robb et al. 2008), which may change vulture behaviour (Deygout et al. 2010, Zuberogoitia et al. 2010), affect fecundity (Carrete et al. 2006) or favour particular individuals or species (Margalida 2010, Moreno-Opo et al. 2010), including the more dominant Gyps species (CortésAvizanda et al. 2010). These risks were minimised in Cambodia, by staggering the dates of the restaurants at the different sites, allowing vultures to potentially move between restaurants across the range, and preventing birds from becoming accustomed to a single site (Deygout et al. 2009). There was no evidence that restaurants favoured any particular species, and all three species seemed to be attracted by greater aggregations of birds. Changing the types of food provided at restaurants, including bigger or smaller carcasses, could further favour increased diversity of vulture species and other scavengers. Long-term provisioning through vulture restaurants is likely to prove a critical conservation management activity, given that Cambodian vultures have limited food sources and restaurants can increase available food supplies in the area by up to $50 \%$.

Food provisioning should be undertaken with local schemes to locate and protect vulture colonies and a legal ban on diclofenac to ensure the survival of vulture populations. The Royal Government of Cambodia has instituted measures to ban diclofenac, and their demonstrable commitment to vulture conservation is greatly welcomed. Local payments to protect nests can be a cost-effective way to increase breeding success (Clements et al. 2010). The most significant conservation challenge remaining is to reduce the apparently high levels of direct and indirect persecution of vultures, particularly from poisoning (responsible for $74 \%$ of deaths) and shooting. Conservation education and advocacy to minimise poisoning and direct persecution will be essential to limit such losses.

\section{Acknowledgements}

The Cambodia Vulture Conservation Project is a collaboration between the General Department of Administration for Nature Conservation and Protection (GDANCP) of the Ministry of Environment (MoE), the Forestry Administration (FA) of the Ministry of Agriculture, Forestry and Fisheries (MAFF), the Wildlife Conservation Society (WCS), BirdLife International in Indochina, World Wide Fund for Nature (WWF), the Angkor Centre for Conservation of Biodiversity (ACCB) and Wildlife Alliance. We would like to thank the Royal Society for the Protection of Birds (RSPB), the Disney Wildlife Conservation Fund, the Global Environment 
Facility - United Nations Development Program, the Darwin Initiative and the Critical Ecosystem Partnership Fund for their support. The Critical Ecosystem Partnership Fund is a joint initiative of l'Agence Française de Développement, Conservation International, the Global Environment Facility, the Government of Japan, the MacArthur Foundation and the World Bank. A fundamental goal is to ensure civil society is engaged in biodiversity conservation. Comments from Antoni Margalida, Ainara Cortés-Avizanda and an anonymous reviewer greatly improved an earlier draft. Finally, we would like to thank Eleanor Briggs for her unwavering support for conservation in Cambodia over the years.

\section{References}

Baillie, J. E. M., Hilton-Taylor, C. and Stuart, S. N., eds. (2004) 2004 IUCN Red List of Threatened Species. A global species assessment. Gland, Switzerland and Cambridge, UK: IUCN.

Barzen, J. (1995) Other SIS sightings in northeastern Cambodia. Specialist Group on Storks, Ibises and Spoonbills Newsletter 7: 4-5.

BirdLife International (2008) Threatened birds of the world. Online at http://www. birdlife.org. Cambridge, UK: BirdLife International.

Brickle, N., Nguyen Cu, Ha Quy Quynh, Nguyen Thai Tu Cuong and Hoang Van San (1998) The status and distribution of Green Peafowl Pavo muticus in Dak Lak Province, Vietnam. Hanoi: BirdLife International Vietnam Programme / Institute of Ecology and Biological Resources. (Conservation Report I).

Burnham, K. P., Anderson, D. R. and Huyvaert, K. P. (201I) AIC model selection and multimodel inference in behavioral ecology: some background, observations, and comparisons. Behav. Ecol. Sociobiol. 65: 23-35.

Carrete, M., Donázar, J. A. and Margalida, A. (2006) Density-dependent productivity depression in Pyrenean Bearded Vultures: implications for conservation. Ecol. Appl. 16: 1674-1682.

Cheke, A. (1972) Where no vultures fly. World of Birds 2: 15-22.

Clements, T. J. John, A., Nielsen, K., An, D., Tan, S. and Milner-Gulland, E. J. (2010) Payments for biodiversity conservation in the context of weak institutions: Comparison of three programs from Cambodia. Ecol. Econ. 69: 1283-1291.
Cortés-Avizanda, A., Carrete, M., and Donázar, J. A. (2010) Managing supplementary feeding for avian scavengers: Guidelines for optimal design using ecological criteria. Biol. Conserv. 143: 1707-1715. Cuthbert, R., Green, R. E., Ranade, S., Saravanan, S., Pain, D. J., Prakash, V. and Cunningham, A. A. (2006) Rapid population declines of Egyptian vulture (Neophron percnopterus) and Red-headed vulture (Sarcogyps calvus) in India. Anim. Conserv. 9: 349-354.

Danielsen, F., Burgess, N. D., Balmford, A., Donald, P. F., Funder, M., Jones, J. P. G., Alviola, P. A., Balete, D. S., Blomley, T., Brashares, J., Child, B., Enghoff, M., Fjeldså, J., Holt, S., Hübertz, H., Jensen, A. E., Jensen, P. M., Massado, J., Mendoza, M., Ngaga, Y., Poulsen, M. K., Rueda, R., Sam, M., Skielboe, T., Stuart-Hill, G., Topp-Jørgensen, E. and Yonten, D. (2008) Local participation in natural resource monitoring: a characterization of approaches. Conserv. Biol. 23: 31-42.

Das, D., Cuthbert, R. J., Jakati, R. D. and Prakash, V. (2011) Diclofenac is toxic to the Himalayan Vulture Gyps himalayensis. Bird Conserv. Internatn. 21: 72-75.

del Hoyo, J., Elliott, A. and Sargatal, J., eds. (1994) Handbook of the birds of the world. Volume 2: New World vultures to guineafowl. Barcelona: Lynx Edicions.

Deygout, C., Sarrazin, F., Gault, A., and Bessa-Gomes, C. (2009) Modeling the impact of feeding stations on vulture scavenging service efficiency. Ecol. Model. 220: 1826-1835.

Deygout, C., Gault, A., Duriez, O., Sarrazin, F. and Bessa-Gomes, C. (2010) Impact of food predictability on social facilitation by 
foraging scavengers. Behav. Ecol. 21: 11311139.

Desai, A. and Lic Vuthy (1996) Status and distribution of large mammals in eastern Cambodia: results of the first foot surveys in Mondulkiri and Rattanakiri Provinces. Phnom Penh: IUCN/FFI/WWF Large Mammal Conservation Project.

Duckworth, J. W. and Hedges, S. (1998) Tracking tigers: a review of the status of tiger, Asian elephant, gaur, and banteng in Vietnam, Lao, Cambodia, and Yunnan province (China) with recommendations for $\mathrm{fu}$ ture conservation action. Hanoi, Vietnam: WWF Indochina Programme.

Duckworth, J. W., Salter, R. E. and Khounboline, K., eds. (1999) Wildlife in Lao PDR: 1999 status report. Vientiane: IUCN-The World Conservation Union / Wildlife Conservation Society / Centre for Protected Areas and Watershed Management.

Eames, J. C., Nguyen Duc Tu, Le Trong Trai, Dang Ngoc Can, Ngo Van Tri, Hoang Duc Dat, Thai Ngoc Tri and Nguyen Thi Thu He (2004) Final biodiversity report for Yok Don National Park, Dak Lak Province, Vietnam: Creating protected areas for resource conservation using landscape ecology (PARC) project. Hanoi: FPD/UNOPS/ UNDP/Scott Wilson Asia-Pacific Ltd/ Environment and Development Group and Forest Renewable Resources Ltd.

Eu Asac (2009) Weapons destruction table 1999-2006. EU ASAC (European Union's Assistance on Curbing Small Arms and Light Weapons in the Kingdom of Cambodia) website www.eu-asac.org. Accessed 15 May 2009.

Gerlach, H. (1994) Chapter 32, Viruses. Pp. 862-948 in B. W. Ritchie, G. J. Harrison and L. R. Harrison eds. Avian medicine: Principles and application. Lake Worth, Florida: Zoological Education Network.

Gilbert, M., Watson, R. T., Virani, M. Z., Oaks, J. L., Ahmed, S., Chaudhry, M. J. I., Arshad, M., Mahmood, S., Ali, A. and Khan, A. A. (2006) Rapid population declines and mortality clusters in three Oriental white-backed vulture Gyps bengalensis colonies in Pakistan due to diclofenac poisoning. Oryx 40: 388-399.
Gilbert, M., Watson, R. T., Ahmed, S., Asim, M. and Johnson, J. A. (2007) Vulture restaurants and their role in reducing diclofenac exposure in Asian vultures. Bird Conserv. Internatn. 17: 63-77.

Goes, F. (1999) Notes on selected bird species in Cambodia. Forktail 15: 25-27.

González, L. M., Margalida, A., Sánchez, R. and Oria, J. (2006) Supplementary feeding as an effective tool for improving breeding success in the Spanish imperial eagle (Aquila adalberti). Biol. Conserv. 129: 477-486.

Gray, T. N. E., Phan, C., Pin, C., and Prum, S. (2011) Establishing baseline ungulate densities in Mondulkiri Protected Forest and Phnom Prich Wildlife Sanctuary. Phnom Penh, Cambodia: WWF.

Green, R. E., Newton, I., Shultz, S., Cunningham, A. A., Gilbert, M., Pain, D. J. and Prakash, V. (2004) Diclofenac poisoning as a cause of vulture population declines across the Indian subcontinent. J. Appl. Ecol. 41: 793800.

Green, R. E., Taggart, M. A., Das, D., Pain, D. J., Sashikumar, C., Cunningham, A. A. and Cuthbert, R. (2006) Collapse of Asian vulture populations: risk of mortality from residues of the veterinary drug diclofenac in carcasses of treated cattle. J. Appl. Ecol. 43: 949-956.

Hla, H., Shwe, N. M., Htun, T. W., Zaw, S. M., Mahood, S., Eames, J. C. and Pilgrim, J. D. (2011) Historical and current status of vultures in Myanmar. Bird Conserv. Internatn. 21: $376-387$.

Hernández, M. and Margalida, A. (2008) Pesticide abuse in Europe: effects on the Cinereous Vulture (Aegypius monachus) population in Spain. Ecotoxicology 17: 264-272.

Hernández, M. and Margalida, A. (2009) Poison-related mortality effects in the endangered Egyptian vulture (Neophron percnopterus) population in Spain. Eur. J. Wild. Res. 55: 415-423.

Houston, D. C. (1985) Indian white-backed vulture Gyps bengalensis. Pp. 465-466 in I. Newton and R. D. Chancellor, eds. Conservation studies on raptors. Cambridge, UK: International Council for Bird Preservation. (Technical Publication No. 5). 
Jathanna, D., Karanth, K. U. and Johnsingh, A. J. T. (2003) Estimation of large herbivore densities in the tropical forests of southern India using distance sampling. J. Zool. (Lond.) 2003: 285-290.

Kenward, R. E. (2001) A manual for wildlife radio tagging. London: Academic Press.

Kenward, R. E, South, A. B. and Walls, S. S. (2003) Ranges6 v1.2: For the analysis of tracking location data. Online manual. Wareham, UK: Anatrack Ltd.

Krebs, C. J. (1966) Demographic changes in fluctuating populations of Microtus californicus. Ecol. Monogr. 36: 239-273.

Krebs, C. J. (2009) Ecology. 6th edition. San Francisco: Benjamin Cummings.

Le Xuan Canh, Pham Trong Anh, Duckworth, J. W., Vu Ngoc Thanh and Lic Vuthy (1997) A survey of large mammals in Dak Lak Province, Vietnam. Hanoi: WWF/IUCN.

Long, B., Swan, S. and Kry Masphal (2000) A wildlife survey of north-eastern Mondulkiri Province. Hanoi: Fauna and Flora International.

Margalida, A. (2010) Supplementary feeding during the chick-rearing period is ineffective in increasing the breeding success in the bearded vulture (Gypaetus barbatus). Eur. J. Wildl. Res. 56: 673-678.

Meretsky, V. J. and Mannan, R. W. (1999) Supplemental feeding regimes for Egyptian vultures in the Negev Desert, Israel. J. Wildl. Manage. 63: 107-115.

Moreno-Opo, R., Margalida, A., Arredondo, A., Guil, F., Martín, M., Higuero, R., Soria, C. and Guzmán, J. (2010) Factors influencing the presence of the Cinereous Vulture Aegypius monachus at carcasses: food preferences and implications for the management of supplementary feeding sites. Wildl. Biol. 16: $25-34$.

Mundy, P., Butchart, D., Ledger, J. and Piper, S. (1992) The vultures of Africa. London: Academic Press.

Naoroji, R. (2007) Birds of prey of the Indian subcontinent. New Delhi, India: Om Books.

NDDB (2006) Indian national dairy development board livestock populations in India. Accessed online on 23/02/2006 at http:// www.nddb.org/statistics/population_india_ species.html
Oaks, J. L., Gilbert, M., Virani, M. Z., Watson, R. T., Meteyer, C. U., Rideout, B. A., Shivaprasad, H. L., Ahmed, S., Chaudhry, M. J. I., Arshad, M., Mahmood, S., Ali, A. and Khan, A. A. (2004) Diclofenac residues as the cause of vulture population decline in Pakistan. Nature 427: 630-633.

O'Kelly, H., Evans, T., Stokes, E., An. D., Clements, T., Gately, M., Men, S., Nut, M., Pollard, E. and Walston, J. (2011) Status, trends and potential for recovery of wild ungulates and tigers in a conservation landscape in Indochina. Phnom Penh, Cambodia: Wildlife Conservation Society.

Oro, D., Margalida, A., Carrete, M., Heredia, R. and Donázar, J. A. (2008) Testing the goodness of supplementary feeding to enhance population viability in an endangered vulture. PLoS One 3: e4084.

Pain, D. J., Bowden, C. G. R., Cunningham, A. A., Cuthbert, R., Das, D., Gilbert, M., Jakati, R. D., Jhala, Y., Khan, A. A., Naidoo, V., Oaks, J. L., Parry-Jones, J., Prakash, V., Rahmani, A., Ranade, S. P., Baral, H. S., Senacha, K. R., Saravanan, S., Shah, N., Swan, G., Swarup, D., Taggart, M. A., Watson, R. T., Virani, M. Z., Wolter, K. and Green, R. E. (2008) The race to prevent the extinction of South Asian vultures. Bird Conserv. Internatn. 18: $\mathrm{S}_{30}-\mathrm{S}_{4} 8$.

Pain, D. J., Cunningham, A. A., Donald, P. F., Duckworth, J. W., Houston, D. C., Katzner, T., Parry-Jones, J., Poole, C. M., Prakash, V., Round, P. D. and Timmins, R. J. (2003) Causes and effects of temporospatial declines of Gyps vultures in Asia. Conserv. Biol. 17: 661-671.

Piper, S. E. (2006) Supplementary feeding programmes: how necessary are they for the maintenance of numerous and healthy populations. Pp. 41-50 in D. C. Houston and S. E. Piper, eds. Proceedings of the international conference on conservation and management of vulture populations. Thessaloniki, Greece: Natural History Museum of Crete.

Piper, S. E., Boshoff, A. E. and Scott, H. A. (1999) Modelling survival rates in the Cape Griffon Gyps coprotheres, with emphasis on the effects of supplementary feeding. Bird Study 46 (Suppl.): S230-238. 
Prakash, V. (1999) Status of vultures in Keoladeo National Park, Bharatpur, Rajasthan, with special reference to population crash in Gyps species. J. Bombay Nat. Hist. Soc. 96: 365-378.

Prakash, V., Green, R. E., Pain, D. J., Ranade, S. P., Saravanan, S., Prakash, N., Venkitachalam, R., Cuthbert, R., Rahmani, A. and Cunningham, A. A. (2007) Recent changes in populations of resident Gyps vultures. J. Bombay Nat. Hist. Soc. 104: 129-135.

Prakash, V., Pain, D. J., Cunningham, A. A., Donald, P. F., Prakash, N., Verma, A., Gargi, R., Sivakumar, S. and Rahmani, A. R. (2003) Catastrophic collapse of Indian white-backed Gyps bengalensis and longbilled Gyps indicus vulture populations. Biol. Conserv. 109: 381-390.

$\mathrm{R}$ Development Core Team (2011) R: $A$ language and environment for statistical computing. Vienna, Austria: R Foundation for Statistical Computing. http://www. R-project.org/.

Robb, G. N., McDonald, R. A., Chamberlain, D. E. and Bearhop, S. (2008) Food for thought: supplementary feeding as a driver of ecological change in avian populations. Front. Ecol. Environ. 6: 476-484.

Round, P. D. (1988) Resident forest birds in Thailand. Cambridge, UK: International Council for Bird Preservation (Monograph 2).

Round, P. D. and Chantrasmi, V. (1985) A status report on birds of prey in Thailand. Proc. Third East Asian Bird Protection Conference: 291-297.

Sarrazin, F., Bagnolini, C., Pinna, J. L., Danchin, E. and Clobert, J. (1994) High survival of Griffon vultures (Gyps fulvus fulvus) in a reintroduced population. Auk II1: 853-862.

Srikosamatara, S. and Suteethorn, V. (1995) Populations of gaur and banteng and their management in Thailand. Nat. Hist. Bull. Siam Soc. 43: 55-83.

Swan, G. E., Naidoo, V., Cuthbert, R., Green, R. E., Pain, D. J., Swarup, D., Prakash, V., Taggart, M., Bekker, L., Das, D., Diekmann, J., Diekmann, M., Killian, E., Meharg, A., Patra, R. C., Saini, M. and Wolter, K. (2006) Removing the threat of diclofenac to Critically Endangered Asian vultures. PLoS Biol. 4: 1-8. Protocol Si. Estimating likely MLE of Meloxicam. DOI: 10.1371/journal.pbio.0040066.sdoo1.

Thewlis, R. M., Timmins, R. J., Evans, T. D. and Duckworth, J. W. (1998) The conservation status of birds in Laos: a review of key species. Bird Conserv. Internatn. 8 (supplement): $1-159$.

Timmins, R. J. and Men Soriyun (1998) A wildife survey of the Tonle San and Tonle Srepok river basins in north-eastern Cambodia. Phnom Penh: Fauna and Flora International and Wildlife Protection Office.

Timmins, R. J. and Ou Ratanak (2001) The importance of Phnom Prich Wildlife Sanctuary and adjacent areas for the conservation of tigers and other key species. Hanoi and Phnom Penh: WWF Indochina Programme.

Timmins, R. J., Pech, B. and Prum, S. (2003) An assessment of the conservation importance of the Western Siem Pang area, Stung Treng province, Cambodia. Phnom Penh: WWF Cambodia Program.

WCS, BirdLife International, WWF, MoE and MAFF (2004) Cambodia vulture conservation action Plan. Phnom Penh: Wildlife Conservation Society, BirdLife International, World Wide Fund for Nature, Ministry of Environment and Ministry of Agriculture, Forestry and Fisheries.

Wells, D. R. (1999) The birds of the ThaiMalay Peninsula, Vol. 1: Non-passerines. London: Academic Press.

Wilbur, S. R., Carrier, W. D. and Borneman, J. C. (1974) Supplemental feeding program for California Condors. J. Wildl. Manage. 38: $343-346$.

Wille, C. (2006) How many weapons are there in Cambodia? Small arms survey: Geneva, Switzerland.

Wint, W. and Robinson, T. (2006) Gridded livestock of the world. FAO: Rome.

Zheng Guangmei and Wang Qishan (1998) China Red Data Book of endangered animals: Aves. Beijing: Science Press.

Zuberogoitia, I., Martínez, J. E., Margalida, A., Gómez, I., Azkona, A. and Martínez, J. A. (2010) Reduced food availability induces behavioural changes in Griffon Vultures Gyps fulvus. Ornis Fennica 87: 52-60. 
TOM CLEMENTS ${ }^{1}$, MARTIN GILBERT, HUGO J. RAINEY

Wildlife Conservation Society, 2300 Southern Boulevard, Bronx, NY 10460, USA ${ }^{1}$ and Department of Zoology, University of Cambridge, Downing Street, Cambridge CB2 3 EJ, UK.

JONATHAN C. EAMES

BirdLife International in Indochina, N6/2+3, Lane 25, Lang Ha Street, Hanoi, Vietnam.

SENG TEAK

World Wide Fund for Nature - Cambodia Program, House \#54, Street 352, Boeung Keng Kang I, PO Box 2467, Phnom Penh, Cambodia.

RICHARD CUTHBERT

Conservation Science, Royal Society for the Protection of Birds, The Lodge, Sandy, Bedfordshire, SG19 2DL, UK.

TAN SETHA

Ministry of Agriculture, Forestry and Fisheries, Royal Government of Cambodia, Cambodia.

PECH BUNNAT, SONG CHANSOCHEAT

Ministry of Environment, Royal Government of Cambodia, Cambodia.

*Author for correspondence; email: tclements@wcs.org

Received 31 December 2010; revision accepted 17 January 2012;

Published online 25 April 2012 